\title{
Dominance and Change in the Global Computer Industry: Military, Bureaucratic, and Network State Developmentalisms
}

\author{
Seán Ó Riain
}

\begin{abstract}
This article examines the conditions under which firms in different economies were able to emerge as significant actors in the global computer industry during different time periods. To achieve this, the article divides into three periods the history of the industry in terms of the three major policy regimes that have supported the dominant firms and regions. It argues that these policy regimes can be thought of as state developmentalisms that take significantly different forms across the history of the industry. U.S. firms' dominance over their European counterparts in the 1950s and 1960s was underpinned by a system of "military developmentalism" where military agencies funded research, provided a market and developed infrastructure, but also demanded high quality products. The "Asian Tigers"-Taiwan, Singapore, Hong Kong, and South Korea - in the 1970s and 1980s were able to eclipse their Latin American and Indian rivals due in large part to the significant advantages offered by a highly effective system of "bureaucratic developmentalism," where bureaucratic elites in key state agencies and leading business groups negotiated supports for export performance. The 1990s saw the emergence of a system of "network developmentalism" where countries such as Ireland and Israel were able to emerge as new nodes in the computer industry by careful economic and political negotiation of relations to the United States, reestablished at the center of the industry, and by more decentralized forms of provision of state support for high-tech development. Finally, the conditions under which new regimes can emerge are a consequence of the unanticipated global consequences of previous regimes. While state developmentalisms have been shaped by existing global regimes, they have promoted further and different rounds of industry globalization.
\end{abstract}

Seán Ó Riain is professor of sociology at the National University of Ireland, Maynooth. His research has been primarily on the political economy of high-tech growth in Ireland and elsewhere, and on work and class politics among software developers. He is the author of The Politics of High Tech Growth: Developmental Network States in the Global Economy (Cambridge, 2004).

Studies in Comparative International Development, Spring 2006, Vol. 41, No. 1, pp. 76-98. 


\section{Explaining the Global Information Economy}

he emergence of a global informational economy is one of the most significant
forces shaping the contemporary socioeconomic landscape. In the $1990 \mathrm{~s}$, trade in information and communications technology goods grew at almost double the rate of total trade, which itself almost doubled over that period, and technological standards became increasingly globally integrated (OECD, 2002). These technologies are the basis of a new "techno-economic paradigm," or the constellation of technological innovations and institutional structures that provide the basis for new global processes of production and capital accumulation (Freeman and Louça, 2002; Perez, 2001). The computer sits at the center of this sector, an iconic industry for the information age and a flagship industry for aspiring developing nations. Different economies have dominated, challenged, and emerged at different stages of the history of the computer industry - from the United States in the postwar era, to the East Asian Tigers in the 1970s and 1980s and on to a network of high regions, recentered around the United States in the 1990s.

What explains this shifting landscape of the global computer industry? Corporate strategies have clearly been crucial in the evolution of national computer industries and technology leaders have shaped the competitive context for the firms that emerged after them. There are many excellent analyses of the computer industry that trace the connections between firm strategies, interfirm connections, and the evolution of technologies (Lecuyer, 2000; Braun and MacDonald, 1978). Global barriers to entry and network structures in computers are also profoundly shaped by the hierarchical organization of global innovation through corporate organization and networks. The large global firms that continue to dominate technical standards and hold the crucial intellectual property rights can often set the terms of trade and technological development for new entrants (Harrison, 1994). However, there are limits to the focus on corporate strategies and structures in explaining national and international patterns of dominance. In explaining national patterns of dominance through an emphasis on corporate strategies, one needs to identify an accumulation of factors that created a competitive advantage for a particular country's firms at particular times. The question in this article therefore shifts to the conditions under which firms in different economies were able to emerge as significant actors in the global computer industry, as outlined above.

Analyses that emphasize how these successful firms are embedded within broader "systems of innovation"- the network of interfirm relationships, public institutions, occupational communities, and other actors that surround any firm - are useful here. Firms are centers of competence building and are crucial sites for promoting collective learning within the economy - but in promoting this collective learning, firms inevitably become tied in to the broader social worlds, which generate information and knowledge that is relevant to them (Amin and Cohendet, 2004). These include the world of technology (which may be science-based, engineering-based, or craft-based, among others), the world of employee expertise (which again may vary as to whether it is based on professional bodies of knowledge, craft traditions, employee networks, or other forms of knowledge), and the world of organizational and policy knowledge (including public agencies, legal firms, professional bodies, employer associations, and so on). These systems of innovation can be both territo- 
rial (Lundvall et al., 2002; Kim and Nelson, 2000) and sectoral (Malerba, 2003). A vast amount of contemporary research shows that "institutional thickness"- the density of the range of institutions surrounding firms - is absolutely crucial to improving firms' economic performance (see e.g., Saxenian, 1994 on Silicon Valley; Kim and Nelson, 2000 on newly industrializing economies). In many, although not all, cases state and public institutions are central to the system of innovation. In late industrializing economies and in newly emerging industries, states are particularly central to attempts to industrialize (Evans, 1995; Woo-Cumings, 1999; Amsden, 2001). Therefore, this article seeks to explain changing patterns of national dominance in terms of the underlying regime of state developmentalism within which firms in different countries were operating, and traces the emergence of new regimes to the global consequences of each previous regime. In each period, we can identify potential candidates seeking to establish niches, and in some cases even dominance, within the global industry. The article makes three major arguments.

First, we can meaningfully portray the history of the global computer industry in terms of the three major policy regimes that have supported the dominant firms and regions within the industry. An initial period of U.S. dominance developed out of World War II and was later challenged from the 1960s by firms from Japan and the "Asian Tigers"- Singapore, South Korea, and Taiwan. The United States came to rapidly dominate global markets in information technology in the 30 years after World War II-IBM alone accounted for 37 percent of mainframe computer sales (the dominant product within the industry) in 1975 (Dedrick and Kraemer, 1998: 15). Through the 1970s and 1980s, Japan began to catch up with the United States while the leading Asian Tigers grew to be comparable in their technological strength to stable Western European economies (Porter et al., 2000). By the 1990s, U.S. dominance reasserted itself at the center of a global network of high-tech regions in new emerging economies such as Ireland, Israel, and India. Yet this U.S. dominance was reestablished in the context of a much more globally integrated industry and simultaneous dominance of and dependence upon global finance and labor to sustain the new computer industries within the United States itself.

Second, I argue that these policy regimes can be thought of as state developmentalisms that take significantly different forms across the history of the industry. This article argues that the successful national computer industries in each period were those that were embedded within a national industrial policy and system of innovation that was underpinned by a version of state developmentalism. We can expect states to consistently play a role in shaping economic action as the state can provide a vision, which can move the economy beyond damaging equilibria sustained by uncertainty and fragmentation, coordinate economic actors to exploit economic externalities, build the institutions necessary for this purpose, and mediate the conflict created in this process (Chang, 1999; Vartiainen, 1999). How and how much state actors involve themselves directly in corporate strategic decisions varies significantly and the literature on developmental states has probably relied excessively on the East Asian cases in formulating an image of the directive state. It is more accurate usually to see states' developmental efforts as taking the role of "midwife" of new firms and sectors and tending to the "husbandry" of these growing industries (Evans, 1995). Rather than intervening directly in corporate strategies (although they occasionally do), most effective forms of state developmentalism 
provide a range of supportive institutions that bolster systems of innovation and promote the reorganization of existing institutions and interests.

In the computer industry, U.S. firms' dominance over their European counterparts in the 1950s and 1960s was underpinned by a system of "military developmentalism," where military agencies funded research, provided a market, developed infrastructure, but also demanded high quality products. The Asian Tigers in the 1970s and 1980s were able to eclipse their Latin American and Indian rivals due in large part to the significant advantages offered by a highly effective system of "bureaucratic developmentalism," where bureaucratic elites in key state agencies and leading business groups negotiated supports for export performance. The 1990s saw the emergence of a system of "network developmentalism" where countries such as Ireland and Israel were able to emerge as new nodes in the computer industry by careful economic and political negotiation of relations to the United States, reestablished at the center of the industry, and by more decentralized forms of provision of state support for high-tech development.

Third, the article argues that the conditions under which new regimes can emerge are a consequence of the unanticipated global consequences of previous regimes. In each period, the dominant regime was somewhat unstable as the emergence of the new actors in the global industry established the conditions of possibility of the next regime. Global military competition had fueled military developmentalism, which in turn shaped the dominant U.S. firms. These firms began to develop international markets and production networks, which then became the basis of bureaucratic developmental strategies in East Asia. These strategies in turn helped develop a new global computer production network, which has now become the basis of network developmental strategies focused on developing high-tech regions within these networks. This analysis suggests that we must locate particular forms of state action in "time and place" and, more specifically, within particular social conditions, political institutions and discourses, and patterns of international hegemonythe developmental state is likely to emerge in different guises under varying sociopolitical and socioeconomic conditions at different times and places (Ó Riain, 2004).

This article therefore seeks to contribute to our understanding of the changing geography of computer industry dominance through an analysis of the shifting systems of innovation within the global industry, bolstered by different forms of state developmentalism. These national contexts did not usually determine corporate strategies, but provided a context that supported firms' abilities to pursue their strategies effectively — and different national contexts were particularly successful under different conditions. While the article cannot fully explore the interactions between firms and the state, it concentrates on establishing the nature of the key state supports for business under each regime.

In addition to developing our understanding of how computer industries have been shaped by social and political institutions, the article also suggests a reorienting of our perspective on the developmental state toward an understanding of the variety of forms that state developmentalism can take and of the economic, political, and world-historical conditions under which particular forms of "the" developmental state emerge and change (for more detailed discussion of this approach see Ó Riain, 2004). This perspective connects to research on the different "varieties of 
capitalism" across time and space (Soskice and Hall, 2001). However, it is misleading to view these "varieties of capitalism" simply as a matter of national institutional complexes competing in a "world market," as is often implied in that literature (Soskice and Hall, 2001; Burawoy, 2001). These institutional complexes are deeply interdependent and shape each other's developmental trajectories. Institutional systems of innovation and state developmentalisms that become dominant shape the competitive context for new entrants, but can also provide resources if access can be negotiated to them. Each dominant institutional and social world of computer production becomes the global context and foundation for subsequent institutional and social "challengers." Finally, the approach adopted here also suggests that a nuanced view of industrial globalization is required where the fates of contending policy regimes are shaped by the global conditions of the day, but where the successful policy regimes shape the context for the emergence of future "challenger" regimes.

Given the temporal and spatial range of the discussion, the analysis in the rest of this article draws on secondary literature to provide a macro-level analysis of these processes of domination and challenge in each of the three periods of the global computer industry. The analysis briefly explores three aspects of each period: (a) the key features of the dominant model of state developmentalism; (b) how the model of state developmentalism contributed to the success of some national computer industries over their closest rivals; and (c) the global computer industry consequences of the dominant policy regime. In the concluding section, the forms of state developmentalism are compared and the transformation in the position of the United States - dominant at the beginning and end of this 60-year history-is analyzed.

\section{A Framework for the Analysis of State Developmentalisms}

Developmental states occupy a particularly strategic position in this politics of the global economy. They are typically central to the most dynamic centers of capital accumulation, innovation, and employment growth. Economically crucial, they are also politically pivotal. This article sees capitalism as a powerful structuring force for states but as a system of production and consumption that is itself politically embedded. Therefore, widespread as state developmentalism is in the history of capitalism, it has taken different forms under varying domestic and international conditions. It becomes analytically and politically critical to understand the specific form of different developmental state regimes.

Developmental states are still the most likely candidate for boosting an economy beyond the narrow logic of private investment and thereby improving its position in the international division of labor. The state cannot achieve these ends in isolation but depends on its relation to society for its success. In particular, developmental states are characterized by what Peter Evans calls "embedded autonomy." Such states are embedded in local capital through the close social ties between state bureaucrats and domestic business owners and managers. Yet effective developmental state apparatuses retain their autonomy due to the presence of a classic Weberian bureaucracy_-based on meritocratic recruitment and promotion and norms of objective, procedural rationality. While embeddedness allows the state to gather infor- 
mation and mobilize resources, autonomy (safeguarded by bureaucracy) and accountability of state agencies guarantees that national development goals remain central to state action (Evans, 1995).

These states avoid the potentially disastrous predatory relationship between the state and the market or society (Evans, 1995). In such cases, individuals and agencies within the state treat their state power as a resource to be used to plunder resources generated by the market or within society. However, developmental states are typically exclusionary - while an educated labor force organized for learning is critical, labor is typically excluded from the key institutions of the developmental state (Amsden, 1989, Deyo, 1992).

Table 1 provides a brief summary of the differences between military, bureaucratic, and network state developmentalisms along critical dimensions (see Ó Riain, 2004 for a more detailed discussion of bureaucratic and network forms). First, strategies vary across forms of developmentalism, although each form involves an underwriting of private sector development by significant state intervention. Military developmentalism concentrates on developing an industry (in competition with other investment possibilities) by putting in place the key features of any industry-labor, markets, investment capital, and so on. Bureaucratic regimes manage dependency while intervening to create new domestic capabilities to be brought to bear in global markets, while network developmentalisms mediate local and global connections and play a key role in fostering "better" connections to the global.

Second, these various strategies imply quite different social and institutional foundations. Military developmentalist regimes are able to create their own "greenfield" ties in new industries, but these are heavily shaped by existing networks of defense

Table 1

Forms of State Developmentalism

\begin{tabular}{|c|c|c|c|}
\hline & $\begin{array}{c}\text { Military } \\
\text { Developmentalism }\end{array}$ & $\begin{array}{c}\text { Developmentalism } \\
\text { Network }\end{array}$ & $\begin{array}{c}\text { Bureaucratic } \\
\text { Developmentalism }\end{array}$ \\
\hline Collective & Building Industry by & Building National & Building Global \\
\hline Development & Underwriting Key & Champions by & Regions by Mediating \\
\hline Strategies & $\begin{array}{l}\text { Features of Industrial } \\
\text { Organization } \\
\text { - Provision of markets } \\
\text { - Creation of related } \\
\text { professions } \\
\text { - Funding research }\end{array}$ & $\begin{array}{l}\text { Managing Dependency } \\
\text { - } \quad \text { Strategic Use of } \\
\text { Protectionism } \\
\text { - Industrial Subsidies } \\
\text { - Domestic Banking } \\
\text { System }\end{array}$ & $\begin{array}{l}\text { Global Connections } \\
\text { - } \quad \text { Building Local } \\
\text { Networks around } \\
\text { Global Capital } \\
\text { - Taking Local } \\
\text { Innovation Networks } \\
\text { Global }\end{array}$ \\
\hline \multicolumn{4}{|l|}{ Institutions } \\
\hline Embeddedness & $\begin{array}{l}\text { Embedded in Military } \\
\text { Industrial Complex; Big } \\
\text { Science and Domestic }\end{array}$ & $\begin{array}{l}\text { Embedded in Domestic } \\
\text { Capital }\end{array}$ & $\begin{array}{l}\text { Multiply Embedded in } \\
\text { Capital Fractions of } \\
\text { Domestic and } \\
\text { International Capital }\end{array}$ \\
\hline Autonomy & $\begin{array}{l}\text { Military Secrecy and } \\
\text { National Security }\end{array}$ & $\begin{array}{l}\text { Coherence of State } \\
\text { Bureaucracy }\end{array}$ & $\begin{array}{l}\text { Valorization of Industrial } \\
\text { Development Agencies }\end{array}$ \\
\hline Accountability & High Quality Criteria & $\begin{array}{l}\text { Bureaucratic Rules and } \\
\text { Performance Measures }\end{array}$ & $\begin{array}{l}\text { External Evaluations of } \\
\text { Benchmarks }\end{array}$ \\
\hline
\end{tabular}


contracting (Markusen et al., 1986). Bureaucratic developmentalist regimes are characterized by close ties between key state bureaucrats, domestic entrepreneurs, and executives, but network regimes are embedded and multiply in local and foreign capital and local, particularly professional, networks of innovation (Ó Riain, 2004). To avoid capture and clientelism, developmental state agencies must retain some autonomy. The high autonomy typically afforded the military is checked by the high quality standards of much military production, which act as a performance pressure. In bureaucratic regimes, autonomy is secured through a tightly coupled, cohesive Weberian bureaucracy that also provides a degree of accountability through explicit rule based regimes (Evans, 1995). Network regimes may be no less bureaucratic but their multiple embeddednesses are monitored through a loosely coupled state structure subject to external evaluations.

We should not reify these forms of state developmentalism. Although they may appear unyielding in their prime, history suggests that such regimes are only temporarily stable - ultimately failing to walk the tightrope of embedded autonomy and either being captured or becoming overly autonomous and isolated, or creating the conditions through their developmental successes for new actors to emerge on the global stage to challenge them.

\section{Bullets, Bytes, and Bureaucrats: Military Developmentalism and the Rise of the U.S. Computer Industry}

Technological advances and state militarization became intimately linked with the "industrialization of war" from the 1840s onward (McNeil, 1982; Arrighi, 1999). World War II led to what some call the first modern computer, developed through the work of Alan Turing in British code-breaking activities. The war played a critical role in the development of the computer industry as "the degree to which scientists and engineers were mobilized in support of the Allied war effort and the scale of their activities were unprecedented" (Flamm, 1987: 6). World War II enabled a massive state-sponsored mobilization of economic and social resources in support of technological development, an effort that was highly coordinated by a variety of state bureaucracies across the warring nations.

After the war, the support for high-tech research continued-particularly in the United States, which had emerged from the war with its own industrial infrastructure intact and a clear position as the hegemonic power in conflict with the emerging Soviet Union. U.S. government support for the emergence of a computer industry was massive, with the government accounting for the bulk of research and development $(R \& D)$ funding and being the primary market during the critical years when the industry was developing after World War II. Defense remained central to the U.S. system of "military developmentalism."

\section{Military Developmentalism in the United States}

In the years after World War II, U.S. computer firms came to dominate this new industry, in the process developing the industry itself. Why were U.S. firms able to establish such market dominance? This occurred in part because the emerging lead firms were supported in significant ways by nonmarket institutions. In fact, in the 
early stages of the emergence of key sectors such as computers and software, the U.S. federal government was itself a significant market. In the early 1950s, government procurement accounted for 54 percent of the computer market, dropping to 21 percent by 1959 and 10 percent by 1966 - all figures that would be much higher if we took into account the indirect effect of demand from military contractors (Flamm, 1987: 107). Government again played a key role in the later emergence of newer sectors such as software: "as late as the early 1980s, some thirty years after the beginning of software production [and more than ten after the creation of an independent software industry], military demand may have accounted for 50 per cent of total software industry revenues" (Langlois and Mowery, 1994: 68). Military hightechnology development made a critical contribution to the development of the Internet, built originally around the Defense Department's ARPAnet (Newman, 2002).

Research and development for the production of these new technologies was also heavily government funded. Before World War II, less than 20 percent of U.S. computing R\&D funds came from the government. During World War II this jumped to 83 percent, dropped to 54 percent by 1957 and rose again to 64 percent in 1961 (Flamm, 1987). The bulk of this government support was through the military and by far the greater part of that spending was outside the state itself, going as contracts to university and industrial labs. Although federal funding declined between 1965 and 1975 in the face of competition for funding from the Vietnam War and the "moon race," in the 1970s, federal funds accounted for at least 75 percent of math and computer science research in universities (Flamm, 1987; Langlois and Mowery, 1994; Markusen et al., 1986).

In particular, the state played a critical role in the United States in developing the technical communities surrounding high-tech industries such as computers, semiconductors, and software (see Breznitz, 2005 for an interesting perspective on how the military operated as a kind of public space in Israeli high technology). The channeling of funding through the universities only strengthened the position of U.S. universities as leading research institutions worldwide that could attract researchers from all over the world. This is clearest in the case of software, where a new discipline of computer science was created with state sponsorship, rather than semiconductors and aerospace, which built on existing scientific disciplines and academic infrastructures. The SAGE project gave a massive boost to the software programmer labor force, employing 400 programmers in 1959, where approximately 200 in the whole country had the requisite skills only four years before (Flamm, 1987: 122; Langlois and Mowery, 1996: 59). The National Science Foundation and ARPA at the Department of Defense helped significantly in building computer science as a discipline in the 1960s, so that with "virtually no formal programs in Computer Science in U.S. universities in 1959, by 1965 there are 15 offering doctorates in Computer Science and 17 offering Bachelor's degrees" (Langlois and Mowery, 1994: 62). The bulk of this expansion was funded through government funding.

The leading high-tech firms and regions within the United States have been well supported by this model of military developmentalism. Government procurement accounted for about one-sixth of IBM's sales in the late 1950s (Flamm, 1987: 108). Furthermore, government funds paid for 35 percent of research at IBM in 1963, a 
year when IBM was putting together an enormous push to develop the commercial System 360 (Flamm, 1987: 95), which transformed the face of computing. Funds did decline significantly after this, but only once U.S. technological dominance had been established. The military and its link to the universities were also crucial to the development of Silicon Valley (Saxenian, 1994: Chapter 2; Leslie, 2000). This reaches all the way back to the "earliest days of experimentation in the fields of radio, television and military electronics" (Sturgeon, 2000a). Silicon Valley remains the largest recipient of military contracts in the United States (Gray et al., 1999: 295) and military research funds have supported crucial fundamental research in the late 1950s at Fairchild Semiconductor on the integrated circuit, in the 1960s at Stanford Research Institute on communications technologies, and in the 1970s at Xerox PARC on personal computers (Newman, 1998: Chapter 3).

The contribution of the military to the computer industry in the United States was marked by the combination of a massive, centralized military side of the state with an economic ideology that theoretically favored the "free market." The result was a form of military developmentalism with a dominant role for government in both funding development and purchasing the products of that development, but where technology development itself remained largely in private firms that held the proprietary rights to the technology. Strategic decisions regarding technology itself remained largely in the hands of the lead firms and efforts by government to direct technology development itself often failed. While the firms involved in this "early period" of the industry were market actors, they were also embedded in a set of markets, financing, and scientific communities that were heavily supported by public institutions.

\section{U.S. Dominance over Europe}

All these factors point to some of the reasons why the United States outstripped the leading European economies in high-technology industries. Although the military provided the initial impetus for much of European participation in high technology, the scale of the resources committed to military spending generally and technology specifically was in no way comparable to the resources expended within the U.S. Hendry (1990) estimates that U.S. monetary support for the computer industry was about 35 times greater than in the United Kingdom - the country that was closest to the United States in terms of technological prowess in 1950. The weakness of the state commitment to taking a leading role in developing the technology industry is indicated by the pressures placed upon the British National Research Development Corporation, the agency charged with developing the computer industry, to pay its way within five years - effectively forestalling any substantial "missionary" role on the part of that agency. In addition to being "less statist" than the United States, the U.K. high-technology policy regime was also "less market-oriented." The major recipients of British defense funding defined themselves as defense industry producers, not as commercial computing companies, and the British government did not fund business-oriented firms (Evans, 1995: 100). The U.S. state not only channeled funds to specific firms but also was also willing to foster a wide range of market actors and supporting institutions. U.S. funding often went to new firms and the process of learning within the industry was furthered by high rates of mobility 
among engineers, both between private firms and between universities and industry (Hendry, 1990: 163). The strategy of building a single national champion-which in many ways blended the worst features of state and market strategies - backfired badly in Britain as ICL, once a leading global computer company, was bought by Fujitsu in 1991.

The French and German computer industries fared better than the British, despite starting from a less promising technological base. While French government expenditure on computer related R\&D ranked similarly to that of the United Kingdom in the 1970s, German spending was more than twice the U.K. and French levels (Flamm, 1987; Dedrick and Kraemer, 1998: 48). The French state's efforts to promote Groupe Bull as the national champion have conspicuously failed, while the firm that was pushed out of the computer industry (CGE-Thomson) to make way for Bull has flourished (Loriaux, 1999: 273). However, Thomson itself has benefited from state upgrading of telecommunications and public procurement. German efforts to promote a national champion, Siemens, also ran into difficulties although the German computer industry has done significantly better than the French, with a much more vibrant sector of independent technology firms alongside the "national champion."

It turns out then that the U.S. state was more developmental in its practice than the European states, which were often more explicitly developmental in their ideology (Loriaux, 1999). In the United States, the state, particularly through the military, mobilized society to participate in the market, while in Europe, the state incorporated society into itself on a greater scale through the institution of the "national champion."

\section{Global Consequences of Military Developmentalism: Expanding Markets and Foreign Investment}

The United States therefore came to rapidly dominate global markets in information technology - IBM alone accounted for 37 percent of mainframe computer sales (the dominant product within the industry) in 1975 (Dedrick and Kraemer, 1998: 15). This U.S. dominance became the context within which all subsequent attempts to enter the industry developed. But if this dominance formed the context for development strategies around the world, it simultaneously set the stage for the future development of the U.S. industry itself. As Richard Gordon argues "Technical dominance and expansive markets subject to minimal foreign competition provided a high rate of potentially marketable innovations in conjunction with a favorable structure for economic risk taking and technical experimentation" (2001: 15). The high profits, which the leading firms and regions such as Silicon Valley enjoyed, were the basis of continuing rounds of innovation. While government intervention enabled the United States to foster the leading industry, it was also made possible by the U.S. hegemonic position, militarily and within world markets. Kenneth Flamm (1987: 17) points out how crucial international markets were to U.S. firms in gaining increasing returns from their technology_-which could then be plowed back into R\&D to cement further their leading global position.

Many countries pursued a direct connection to the leading high-technology industries by attempting to lure U.S. companies as direct investors in their rapidly 
spreading export processing zones, industrial parks, and free trade zones, which combined infrastructure with special regulatory regimes, which also suspended many of the rights that workers had gained throughout the nation. These efforts attracted many willing investors: "The first EPZ appeared at Shannon, Ireland, in 1958; India established the first Third World EPZ in 1965, and by the mid-1980s roughly 1.8 million workers were employed in a total of 173 EPZs around the world" (McMichael, 1996: 92). Global flows and stocks of foreign direct investment and the volume of global trade increased much more rapidly than world GDP in the late 1960s and the 1970s, before recession and protectionism in the 1980s reined in this particular outburst of globalizing activity (Held et al., 1999: 242). In keeping with this broader trend, in the 1960s, American and Japanese electronics firms began to move production "offshore," first to Korea, Taiwan, Hong Kong, and Singapore; then, beginning in the mid-1980s, throughout Southeast Asia (Henderson, 1989). In expanding their foreign operations from the 1960s onward, Japanese firms were motivated by an interest in servicing Asian markets, and by the attraction of lowwage labor that would facilitate their push into the large and lucrative American market. The strategy of American firms, by contrast, was at first part of a strategy of the globalization of the computer industry and was later largely a defensive antidote to stiff Japanese competition.

\section{Bureaucratic Developmentalism and the Rise of East Asian Electronics}

The East Asian "Tigers" were able to develop dynamic domestic IT industries with great success in international markets by the 1980s, despite beginning from a weak technological basis in the 1960s. A brief review of the development experience of IT in East Asia reveals a set of strategies for development, which incorporated many of the elements of the EPZs and the "bargaining" strategies outlined above, but which put them together into very effective strategies for developing indigenous technological capacity.

\section{Bureaucratic Developmentalism in the Asian Tigers}

Japan was the clearly the greatest "success story" in the international computer industry between the 1960s and the 1980s. Driven forward by an alliance between a cohesive state bureaucracy (with strong informal internal ties based on school affiliations) and the large firms and business groups (keiretsu), a form of "alliance capitalism" emerged that proved remarkably successful in international competition (Gerlach, 1992). In the early 1960s, computers were targeted as a strategic sector for development and a variety of policy measures were put in place. These measures included extensive protection against foreign competition and some hardnosed bargaining with foreign multinationals such as IBM (Dedrick and Kraemer, 1998: 41). Building on a set of economic institutions, which had emerged since the late nineteenth century (Dore, 1973), the Japanese state stimulated domestic demand for Japanese computers, promoted public and private $R \& D$, and provided a variety of investment incentives for domestic firms. Japanese policy combined competition and cooperation in a fruitful mix. Weaker firms were allowed to fail in the face of domestic competition, although protected from foreign competition for long 
periods. "Market competition" was used strategically to promote business development, rather than as an overriding ideological principle. At the same time these competing domestic firms also often engaged in cooperative arrangements - either through R\&D consortia or through connections to the famous Ministry of International Trade and Industry (MITI) or Nippon Telegraph and Telephone (NTT) (Johnson, 1982; Dedrick and Kraemer, 1998).

Similar examples of developmental states emerged elsewhere in East Asiaparticularly in South Korea, Taiwan, and Singapore. Korea pursued a "bureaucratic developmentalism" that was particularly close to the Japanese model, with close ties between a centralized state bureaucracy and the chaebol, or large business groups (Amsden, 1989; Evans, 1995). Electronics was targeted as a critical sector from the early 1970s, and the state provided loans, created cooperative information-sharing institutions, provided a market through procurement, took on some design work, and built an information infrastructure that was used to boost industry production as well as provide infrastructure (Bae, 2000; Evans, 1995; Wade, 1990).

Singapore combined a bureaucratic state with an emphasis on attracting foreign investment rather than fostering the growth of a domestic bourgeoisie. Gregg Huff (1995) argues that the key feature of Singapore's model of development was government control over wages and labor, which enabled the attraction of FDI and the ending of unemployment. This in turn enabled the state to force a high level of domestic savings and these savings were mobilized, largely through state-run contributory funds, to finance building infrastructure - both for business and also for the social reproduction of the population (e.g., through housing provision). Low wages and excellent infrastructure maintained the flow of FDI while the heavy state subsidies of housing and other costs of social reproduction combined with labor repression and incorporation to sustain popular support for the regime. The state's intense labor control ensured low inflation in a context of tight labor supply. There have been significant shifts from a reliance on low-cost labor to upgrading operations in Singapore and sending low-skill work offshore, to attempts to improve local productivity and innovation so that Singapore is increasingly a center of ecommerce and engineering as well as assembly (McKendrick, 2000).

Taiwan's strategy sits somewhere between Korea's and Singapore's, combining foreign and indigenous firms. Whereas information technology foreign investment figures prominently, transnational technical communities and migration ties have been just as important. The Taiwanese state in the 1950s was certainly less "hands on" than the Korean state in directly influencing firm decisions but, although the state did not "pick winners" among firms, it still shaped the activities of firms: "Even after most import and foreign exchange controls were lifted, the government exercised its will through the myriad licenses necessary for a firm to operate; the requirement of prior approval for foreign loans and technology agreements; public ownership of the banking system, which held interest rates much higher than in most Third World countries; vagueness in tax laws such that politically uncooperative firms could be threatened with audits, and so on" (Amsden, 1985: 98).

Ultimately each of these Asian Tigers participated in the global computer industry in different ways. South Korea and Japan's connections to the international economy are funneled through the chaebol and keiretsu, respectively. Taiwan's smaller domestic firms are deeply integrated into what is essentially an extension 
of global IT production networks, while Singapore connects to these networks primarily through the subsidiaries of foreign TNCs (Dedrick and Kraemer, 1998: 223 226). Despite their significant differences, each of these East Asian Tiger economies had a well-established and effective state bureaucracy that exerted a positive effect on development outcomes, net of investment, education, and "convergence" (Rodrik, 1997; Evans and Rauch, 1999; Woo-Cumings, 1999).

\section{Toothless Tigers: Brazil and India}

The Asian Tigers were not the only newly industrializing countries to attempt to build computer industries in the 1960s. Many attempted to emulate the U.S. model of military developmentalism. Brazil and India illustrate some of the typical features of such strategies in countries that had only limited success in the international information technology industry. Both began their computer industries through the leading role of the military in the 1960s. The first computer in Brazil was installed at the navy in 1958. More important, under the military dictatorship from 1964 to 1985, computers and technological autonomy were seen as economically and militarily strategic (Evans, 1995; Luzio, 1996). In India, the initiative for building an indigenous capacity in computer manufacturing came from the nationalist technocrats in the mid-1960s, but jibed well with military geopolitical concerns, which had been fueled by a series of military setbacks in the early 1960s and the U.S. refusal to sell India electronics equipment during the war with Pakistan in 1965 (Evans, 1995: 106). Despite a similar industrial starting point to the Asian Tigers, Brazil and India were unable to build a computer industry of the same size or sophistication.

Both countries initially emphasized state-owned enterprises as the vehicle through which this technological autonomy would be built and sustained. After all, military technological autonomy required close control over indigenous technology. The Electronics Corporation of India, Ltd. (ECIL) was formed in 1967, under the auspices of the Atomic Energy Commission, and while it struggled commercially and particularly in commodity production, it carried out important large-scale systems integration projects within the Indian economy-projects that the smaller private sector firms were poorly placed to carry out (Evans, 1995: 131; Grieco, 1984). In Brazil, a variety of state companies formed Digibras, later to form COBRA making minicomputers in joint alliance with Ferranti of England, which provided the technology and a local firm, which carried out production while Digibras contributed the investment (Luzio, 1996: 4).

India and Brazil therefore both placed great weight on developing "national" computer industries and attempted to combine the development of state-owned enterprises with negotiations with TNCs from behind protectionist barriers into a strategy that could foster the growth of indigenous technological capability. Despite some successes, they were more unsuccessful by the early 1990s in their attempts to generate a vibrant domestic computer industry. Their large domestic markets gave them a resource that could be used in bargaining with TNCs, which was not available to many other smaller countries (Grieco, 1984), but it could not deliver the deep indigenous technological capability that they pursued. Their emphasis on building national champions could not compete with the more thorough 
developmentalism of the Asian Tigers, or with their more effective use of markets to promote domestic competition and development. In this respect, their weakness in relation to the Asian Tigers was similar to that in the previous period of the European countries in relation to the United States.

\section{Global Consequences of Bureaucratic Developmentalism: Globalization and Revival in the U.S. Computer Industry}

State developmentalism was critical in building up the regional economy of East Asia, from within extensive international connections with Japan and the United States, but, in the process, it transformed the character of the international computer industry. Most spectacular, the character of global competition was deeply intensified by the rise of East Asia (Brenner, 2000). But the character of global production was changed, as well as that of global markets. New capacities in the region ironically contributed to the revival of U.S. electronics in the 1990s, a revival that was only in part due to the difficulties of Japanese firms. Japanese firms built hierarchical international production networks - reflecting their successful domestic production strategies. American firms, by contrast, entered into alliances with increasingly sophisticated suppliers, which often emerged through the kinds of local strategies for upgrading described above.

Many U.S. firms came to rely heavily on the production capabilities and technological sophistication of suppliers in the China Circle, Singapore and South Korea - enabling American firms to escape dependence on Japanese suppliers who were also competitors, and to lower costs and improve turnaround times (Borrus, 1997). However, these new suppliers are also potential competitors, suggesting a new axis of global competition with a geographical shift from Japan to the China Circle and an organizational shift from competing hierarchies to competing global networks (Borrus, 1997). This is all the more critical since "first-tier suppliers" or "turnkey contract manufacturers" have come to occupy a critical position in global production networks. These production networks also are increasingly taking on a "merchant" character so that they can be broken and reassembled easily and quickly as the lead U.S. firms have reasserted control over the key technology and marketing functions (Sturgeon, 1999). U.S. high-tech industry has increasingly and effectively integrated East Asian production networks into its own global operations.

Mowery (2001) argues that there has been a gradual shift from U.S. technological hegemony in 1950 to a global multipolar system of not only production but also innovation, extending first to Europe, then Japan, and now even to a select number of NICs: "Specific sites become centers for specific technological competences and attract considerable investments by multinational firms in R\&D and often (because of the need for close links between R\&D and other activities) production" because of "the growing returns to specialization in specific technological activities or competences, some apparent decline in 'scope economies' among specific competences... and the increased international dispersion of these competences" (Mowery, 2001: 151). The United States remains at the center of this system, although now much more closely linked to foreign firms through rising foreign investment in the United States, interfirm alliances and "transnational technical communities" (Saxenian, 1999). This is facilitated in part, Mowery argues, by the 
U.S. system of innovation, which is probably more open than most due to the important role of universities in $\mathrm{R} \& \mathrm{D}$, the market for corporate control, and a liberal U.S. government policy toward FDI (2001: 153).

\section{Network Developmentalism and the Rise of Global Regions}

Taken together, these global developments have seen a new relationship between TNCs and certain regions so that a new international network of regional industrial clusters has become the context for a new form of "network developmentalism" where national states seek to integrate high-tech regions into global production and innovation networks.

\section{Network Developmentalism in Global Regions}

New forms of state developmentalism have emerged in economies such as Israel and Ireland that seek to combine local and global networks of innovation to promote computer industry development. High technology in these economies shares certain common features: each economy has undergone liberalization, to the point where they are "open" to the global economy; each has pursued foreign investment through financial incentives and investment in a technical labor force; and each has seen the emergence of important concentrations of technical skill and innovatory capacity supported by dense social networks of technical professionals and entrepreneurs (Arora et al., 2000; Breznitz, 2002; Ó Riain, 2004). Israel has built on an existing technological base and a foundation of returning migrants from the United States to create a diverse high-tech sector with niche strengths and a large number of Israeli firms which are international "technology leaders" (Breznitz, 2002). Ireland continues to rely heavily on U.S. high-tech foreign investment but has been able to build an Irish high-tech sector alongside, and relatively independent of, this foreign sector (Ó Riain, 2004).

A critical element in "upgrading" these international connections has been the simultaneous fostering of local, territorialized dynamics of learning, innovation, and growth. Fragile technical communities emerged around foreign firms in Ireland and became the basis for a growing indigenous sector. Israel has seen a broad diversification of local interfirm and social networks across a variety of high-tech sectors. In each case, the institutional framework of the region-its associations, educational institutions, support industries, and state agencies and policies - play an ongoing role in shaping the high-tech region. The Irish and Israeli states are more likely to stimulate venture capital investment, create a range of innovation centers, provide R\&D funding, and foster international networks than to try and directly influence firms' business decisions (Ó Riain 2000, 2004; Breznitz, 2002).

In Ireland, state agencies acted to support emerging indigenous industry and to upgrade the national system of innovation in three major ways - defining the character of industrial strategies, implementing company development through grant aid, and creating an associational infrastructure for innovation.

Research into software firms in Ireland shows, for example, that those firms that received the most state grant aid exported more, employed more people, and grew faster. The bulk of early financing of Irish companies came through state-spon- 
sored investment schemes - it was only after growth was well underway in 1999 that private venture capital flooded into Ireland. In 1997, with the Celtic Tiger already roaring, more than a third of private equity investment in Ireland came from state sources, and much of the private investment was stimulated by state incentives for investors (Ó Riain, 2000, 2004).

Israeli high-tech industry, while coming into its own in the $1990 \mathrm{~s}$, has its roots much earlier in Israel's history (Breznitz, 2002). As early as the 1940s and 1950s, science and academic research was highly advanced in Israel, which often occurred through links to the military and, in the 1960s, the connections of the Jewish diaspora-particularly in the United States - to Israel combined with heavy defense investment to produce large, defense-oriented technology firms. State support is extensive for all levels of business development in high technology, and takes the form of matchmaking, investment, and consultative support (Sokolov and Verdoner, 1997). As early as the 1960s, the Israeli government provided capital grants and fostered science parks to build the civilian economy. It was among the earliest states (if not the first) to give R\&D grants to individual firms (Roper and Frenkel, 1998). The state has also been central to the provision of venture capital, beginning its efforts in 1985. However, success came only with the Yozma scheme, operating since 1993, which shares the risk of loss with firms and provides favorable terms to successful firms for buying back the Yozma shares (Sokolov and Verdoner, 1997; Breznitz, 2002). Links to the United States are extensive in all areas of high-tech industry, and policy ties through interfirm alliances and transnational technical communities are more critical to Israeli high technology than foreign investment. Ultimately, the Israeli state no longer picks industrial "winners" or directly influences their decisions, but has constructed a range of institutions that effectively foster innovation and learning, support business development, and channel firms toward particular kinds of activities (such as R\&D) that contribute to more durable economic success.

\section{Global Regions Challenge Bureaucratic Development}

While the Irish and Israeli states are active in promoting high technology, they have done so in ways that are often quite different from the "developmental states" of Japan and Korea. These network developmentalisms attempt to nurture localized post-Fordist networks of production and innovation within global investment flows by shaping the character of the various local connections to global technology and business networks. The highly concentrated industrial structure and capacity to mobilize large sunk investments, which had been strengths of the Japanese and Korean industrial systems in markets such as memory chip production, were now liabilities in rapidly changing markets such as PCs and software where network connections were often as critical as large in-firm investments (Dedrick and Kraemer, 1998). Marie Anchordoguy (2000) argues that Japan's reliance on state targeting, centralized business groups, bank-centered financing, weak intellectual property, and production engineering - so crucial to its success in mechanical engineering, steel, semiconductors, and computer hardware-were liabilities in the networked world of software design (we might add personal computers, data communications, information services). 
Taiwan has had perhaps the greatest success of the Asian Tigers in responding to the changed global conditions. Export processing zones were put in place after 1965 but, over time, the Taiwanese economy became much less dependent on foreign investment as Taiwanese firms were able to upgrade their positions within international production networks - moving toward OEM, ODM, and even innovation (Saxenian and Hsu, 2001; Hobday, 1995). This upgrading was attained through an increasingly complex and interlocking set of international and local networksincluding not just FDI but also overseas Chinese who had received university education in the United States and had long experience and close social ties to centers of technological innovation such as Silicon Valley (Saxenian and Hsu, 2001). Yet these international connections were grounded locally by a growing institutional thickness within the Taiwanese political economy, particularly around information technology. A range of powerful institutions were developed to support high-technology entrepreneurship and innovation-including the centers for technological research such as Electronics Research \& Service Organization (ERSO), the Hsinschu Science-Based Industrial Park (HSIP), industry-university linkages, and industry and professional associations (Hsu, 1997; Meaney, 1994). Whereas South Korea and Japan hardly faded as actors in the global computer industry, Taiwan most effectively transformed its policy and industrial system to integrate into the new industrial landscape.

\section{Global Consequences of Network Developmentalism: Globalizing the Reproduction of U.S. Dominance (and Dependence)}

Each of these "national" computer industries is closely integrated with the U.S. industry. The U.S. high-tech industry itself continues to benefit from its historical dominance within international high technology. U.S. companies have also been able to retain control over almost all the technical standards within microprocessors and software - a control that even the Japanese companies have been unable to wrest away from them in the face of the very significant network externalities and increasing returns that build up around standards holders (Dedrick and Kraemer, 1998: 90). The increasing importance of the "cultural content" of traded products also advantages U.S. companies, given the relative U.S. cultural hegemony worldwide. It is interesting, for example, that Japan has been able to steal away this advantage in video games, which are oriented toward action and not language, and appeal to a widespread set of cross-culturally understood elements of masculinity.

However, the character of U.S. dominance of global high technology has been transformed through the events outlined above. Where the U.S. computer industry, underpinned by military developmentalism, had once practically created global markets and investment, it now sits at the center of a network of complex international ties. The first of these sets of ties is the flow of labor. AnnaLee Saxenian (1999: 10) points out that in 1965 only 47 scientists and engineers immigrated to the United States from Taiwan but in 1967, two years after the Immigration Act liberalizing immigration from non-European countries, 1,321 did so. This increase was further boosted by a 1990 act that almost tripled the annual quota of visas based on occupational skills. Some 24 percent of the Silicon Valley labor force was 
foreign born in 1990, rising to 29 percent in high-tech industries and 32 percent of engineers. Two-thirds of these are Asian, with the vast majority from India or China, especially Taiwan. There also has been a huge increase in the number of Chinese students receiving doctorates in the United States in the 1990s, while the numbers from India, Taiwan, and South Korea have remained stable. Non-U.S. labor has been critical to U.S. high-tech growth and immigration has solved an enormous problem of labor supply in the industry.

These global ties go beyond labor supply to the entrepreneurial and associational dynamics of U.S. high technology. Saxenian reports that in 1998 some 24 percent of Silicon Valley firms had an Indian or Chinese CEO, suggesting a very high (and probably underestimated) rate of entrepreneurship among these groups (1999: 23). This has increased over time, with 13 percent of those firms started between 1980 and 1984 having Indian or Chinese CEOs while 29 percent of those started between 1995 and 1998 have (1999: 24). The immigrant entrepreneurs rely heavily on various ethnic professional associations in Silicon Valley (Saxenian, 1999: Chapter 3). These associations provide valuable mentoring, information, and networks to people with extensive resources, including large amounts of venture capital. Chinese and Indian high-tech professionals operate across a complex set of overlapping local and transnational networks within and across ethnic boundaries. In the process, they add a valuable dimension to the vibrant regional economies of places such as Silicon Valley - as the once closed military industrial complex becomes inextricably linked to transnational capital and labor.

Financing, too, has been heavily shaped by international ties — as the United States has become a major destination for investment funds, international financial flows proved crucial to maintaining the investment boom of the 1990s that was so central to the "dot.com" surge in the computer industry (Silver and Arrighi, 2003). The character of the U.S. computer industry - and the global regions with which it is ever more closely tied - is deeply shaped by the financialization of the U.S. economy in recent decades.

Various states around the world have played a critical role in the U.S. high-tech success, and its place at the heart of increasingly significant global networks of finance, production, innovation, and migration has enabled the U.S. economy to reap the benefits. Nonetheless, this is a much more restricted role for the state in high technology than in many other economies around the world. Part of the reason for this is that there is less "need" for a state role within the hegemonic power in the industry. However, this argument can only take us so far. U.S. leadership was seriously challenged in the 1980s by Japan in particular and the U.S. state did act in response to that threat, albeit largely through protectionism and pressures on Japan to "open" their markets. Meanwhile, the basis of U.S. industrial leadership was increasingly shaky as the most basic requirements of the industry, a steady supply of educated labor and a "world class" production capacity, were in danger of not being met within the United States. The number of graduates with computing degrees fell steadily from the mid-1980s and U.S. production quality had fallen dramatically behind the East Asian economies in the 1980s. In both of these respects, U.S. high-tech industry has been heavily supported by the actions of states other than the U.S. state. U.S. industry has been able to avail of extensive government investments in technical education around the world through the migration of skilled 
labor and degree-level students, while global production networks in East Asia have enabled the U.S. industry to piggyback upon the state-sponsored advances in production within that region.

The U.S. state itself became more active in the global protection of the conditions of market dominance, promoting "Wintelism" (the dominant technological alliance between Intel and Microsoft) and high-tech intellectual property rights internationally through the aggressive use of multilateral and, in the meantime, bilateral, trade policy to punish countries with less strict enforcement of international copyright laws (Hart and Kim, 2001). Kenneth Shadlen et al., (2005) argue that an extensive and effective international institutional regime has emerged in software where the United States, WTO, and other related institutions promote the protection of intellectual property rights in a wide range of countries, with uncertain and worrying consequences for innovation.

\section{State Developmentalisms in the Global Information Economy}

This article argues that we can meaningfully describe the key periods of the history of the global computer industry in terms of the three major policy regimes that have supported the dominant firms and regions within the industry. This article also argues that these policy regimes can be thought of as state developmentalisms, which take significantly different forms across the history of the industry, and that the conditions under which new regimes can emerge result from the unanticipated global consequences of previous regimes. State developmentalisms have been crucial to the computer industry, but they have varied significantly across time and place. While they have been shaped by existing global regimes, they have promoted further and different rounds of industry globalization.

Each type of state developmentalism - military, bureaucratic, and networkshares certain characteristics. Each form placed more emphasis on shaping the conditions under which firms operated, rather than directly influencing business and technology decisions. In this respect, state developmentalisms veered closer to the market model than to state production or even detailed planning (although in each case, some of this was present and important). Yet each form of developmentalism also went well beyond setting ground rules for market functioning to shape markets, financing, labor supply, international ties, and even the social structure of innovation itself. In each era, the "failed"-or at least less successful cases of developmentalism - were both less statist and less market-oriented than the successful cases that created significant supports within which market activity was embedded.

Nonetheless, each type of state developmentalism has taken a different form from the others. Military developmentalism used defense spending to create the basic infrastructure of a new industry - creating the infrastructure for academic and business R\&D and providing many of the early markets into which their products could be sold. However, the companies that were formed as global leaders were relatively free of state influence and in many cases resisted any form of close embrace with the state.

The bureaucratic developmentalism of the Asian Tigers tended to hold firms closer, particularly through the crucial links among government agencies, banks, 
and large firms. There was a much closer relationship between firms and the statealthough firms may have been equally interested in escaping the embrace of the state as in the United States, the institutional conditions made it much more difficult for them to do so. Nonetheless, an effective system of supports for sustained investment and learning by firms and business groups developed and was crucial to the rise of the Asian Tigers.

The Japanese case illustrates the futility of approaching the issue in terms of "state versus market." The Japanese case was both less state-oriented and less market-oriented than the U.S. case. The extent of U.S. direct state subsidy was much greater than in Japan, which tended to operate through dense social networks to mobilize coalitions of private actors including the financial and industrial power of the keiretsu. On the other hand, the Japanese state played a much greater role in shaping the actions of firms within the market.

Finally, network developmentalism has seen the role of the state transformed again. The state is now more pervasive than ever before - shaping almost any aspect of the economic and social environment in the interests of business (Cerny, 1995). But its touch is everywhere lighter when it comes to business itself. The developmental network state becomes a facilitator and broker as well as its traditional roles of investor, buyer, and financier.

Finally, the evolution of the global computer industry has apparently taken us full circle from U.S. dominance after World War II through the East Asian challenge and back to U.S. dominance. Even leaving the questions of the degree of U.S. dominance aside, it is clear that the U.S. finds itself in a different position today. Where in the 1950s the United States constituted the vast majority of the global computer industry, today's U.S. firms and policymakers find themselves working through international networks - of finance, labor, scientific, and technological innovation - that are shaped by interacting policy regimes. If international networks serve to integrate emerging industries into the U.S.-centered industry, they also pose significant uncertainties and dilemmas of governance for both firms and dominant states. This is all the more telling in an era when the Bush administration's agenda is based on harnessing information technology in the service of tightly nationally controlled surveillance structures and force, but when the system of production of those technologies is deeply networked internationally.

Each of the most significant transitions in the history of the global information economy has been driven by a state developmentalism, which has gone beyond the economic calculus of the day to construct a system of innovation that undertakes and promotes new activities that are not supported by "the market." These new institutional constellations that promote new markets in information technology are organized on a broader geographical scale, drawing in new territories and expanding markets. But if markets have been expanded internationally, so too have a dense network of social institutions - interfirm networks, governmental treaties, transnational technical communities, migration flows, and so on. The contemporary international computer industry is not one of a pure free market but one in which markets are deeply structured, and even made possible by the historical and spatial accumulation of multiple forms of technical community, sustained by multiple forms of state developmentalism interacting across an expanding transnational "social world of information technology." 
The political foundations of the global computer industry are all the more critical since the informational techno-economic paradigm is most likely approaching a period of institutionalization after a period of boom (Perez, 2001). After the bubble of the 1990s, it seems likely that a period of struggle is now likely to ensue regarding the new modes of regulation and social forms that will become institutionalized around the computer industry and the broader information economy. The dominant social organization of the global information economy remains to be determined, but the struggles over its future relations of production and innovation will depend greatly upon those social and institutional foundations that we have outlined above.

\section{Note}

* Thanks to the two anonymous reviewers who provided extensive and helpful comments.

\section{References}

Amin, A., and P. Cohendet. 2004. Architectures of Knowledge: Firms, Capabilities and Communities. Oxford: Oxford University Press.

Amsden, A. 1985. “The State and Taiwan's Economic Development” In P. Evans et al., eds., Bringing the State Back In. Pp. 78-106 Cambridge: Cambridge University Press.

. 1989. Asia's Next Giant: South Korea and Late Industrialization. Oxford: Oxford University Press.

. 2001. The Rise of "the Rest": Challenges to the West from Late-Industrializing Economies. Oxford: Oxford University Press.

Arora, A., A. Gambardella, and S. Torrisi. 2000. "In the Footsteps of Silicon Valley? Indian and Irish Software in the International Division of Labor" Stanford Institute for Economic Policy Research Discussion Paper 00-041.

Arrighi, G. 1999. "Globalization, State Sovereignty and the 'Endless' Accumulation of Capital” In D. Smith, D. Solinger, and S. Topik. States and Sovereignty in the Global Economy. Pp. 53-72 London and New York: Routledge.

Arrighi, G., and B. Silver. 2001. Chaos and Governance in the Modern World System. Minneapolis: University of Minnesota Press.

Borrus, M. 1997. "Left for Dead: Asian Production Networks and the Revival of US Electronics" BRIE Working Paper 100. Berkeley: Berkeley Roundtable on the International Economy.

Braun, E., and S. MacDonald, 1978. Revolution in Miniature. Cambridge: Cambridge University Press.

Brenner, R. 2002. The Boom and the Bubble. London: Verso.

Breznitz, D. 2005. "Collaborative Public Space in a National Innovation System: A Case Study of the Israeli Military's Impact on the Software Industry." Industry and Innovation (12,1): 31-64.

Burawoy M. 2001. "Neoclassical Sociology: From the End of Communism to the End of Classes" American Journal of Sociology 106, 4: 1099-1120.

Chibber, V. 1999. "Building a Developmental State: The Korean Case Reconsidered." Politics and Society 27,3: 309-346.

Dedrick, J., and K.L. Kraemer. 1998. Asia's Computer Challenge: Threat or Opportunity for the United States and the World? Oxford: Oxford University Press.

Dore, R. 1973. British Factory, Japanese Factory: The Origins of National Diversity in Industrial Relations. London and Boston: Allen and Unwin

Evans, P.B. 1995. Embedded Autonomy. Princeton, NJ: Princeton Univ. Press.

Evans P.B., and J. Rauch. 1999. "Bureaucracy and Growth: A Cross-National Analysis of the Effects of 'Weberian' States Structures on Economic Growth.” American Sociological Review 64: 748 765.

Flamm, K. 1987. Targeting the Computer: Government Support and International Competition. Washington D.C.: The Brookings Institution.

Freeman, C., and J. Hagedoorn. 1994. "Catching Up or Falling Behind: Patterns in International Interfirm Technology Partnering” World Development 22, 5: 771-780. 
Freeman, C., and Louca, F. 2002. As Time Goes by: From the Industrial Revolutions to the Information Revolution. Oxford: Oxford University Press.

Gereffi, G. 1994. "The International Economy” In N. Smelser and R.Swedberg, eds., The Handbook of Economic Sociology. Princeton, NJ: Princeton University Press/Russell Sage Foundation.

Gerlach, M. 1992. Alliance Capitalism: The Social Organization of Japanese Business. Berkeley: University of California Press.

Gordon, R. 2001. "State, Milieu, Network: Systems of Innovation in Silicon Valley.” Center for Global, International and Regional Studies Working Paper \#2001-3. University of California, Santa Cruz (originally distributed in February 1994).

Grieco, J. 1984. Between Dependency and Autonomy: India's Experience with the International Computer Industry. University of California Press: Berkeley.

Harrison, B. 1994. Lean and Mean. New York: Basic Books

Hart, J., and S. Kim. 2001. "The Global Political Economy of Wintelism: A New Mode of Power and Governance in the Global Computer Industry," in James N. Rosenau and J.P. Singh, eds., Information Technologies and Global Politics: The Changing Scope of Power and Governance Albany, N.Y.: SUNY Press.

Held, D., A. McGrew, D. Goldblatt, and J. Perraton. 1999. Global Transformations: Politics, Economics and Culture. Stanford: Stanford University Press.

Henderson, J. 1989. The Globalization of High Technology Production. New York: Routledge.

Hendry, J. 1989. Innovating for Failure: Government Policy and the Early British Computer Industry. Cambridge, MA MIT Press

Hobday, M. 1994. "Technological Learning in Singapore: A Test Case of Leapfrogging." The Journal of Development Studies 30, 3: 831-858.

- M. 1995. "East Asian Latecomer Firms: Learning the Technology of Electronics" World Development 23, 7: 1171-1193.

Hsu, J.Y. 1997. “A Late Industrial Distrcomputer? Learning Networks in the Hsinchu Science-based Industrial Park." Taiwan. Ph.D. Dissertation, Department of Geography, University of California, Berkeley.

Huff, W. 1995. "The Developmental State, Government and Singapore's Economic Development since 1960." World Development (23, 8): 1421-38.

Johnson, C. 1982. MITI and the Japanese Miracle. Stanford, CA: Stanford University Press

Kim, L., and R. Nelson, 2000. Technology, Learning and Innovation: Experiences of Newly Industrializing Economies. Cambridge: Cambridge University Press.

Langlois, R., and D. Mowery. 1996. "The Federal Government Role in the Development of the US Software Industry.” In D. Mowery, ed., The International Computer Software Industry. Pp. 53 85. Oxford: Oxford University Press.

Lécuyer, C. 2000. "Fairchild Semiconductor and Its Influence.” In Chong-Moon Lee, William Miller, Marguerite Hancock, and Henry Rowen, eds., The Silicon Valley Edge: A Habitat for Innovation and Entrepreneurship. Stanford: Stanford University Press.

Leslie, S. 2000. "The Biggest 'Angel' of Them All: The Military and the Making of Silicon Valley" In M. Kenney, ed., Understanding Silicon Valley. Pp. 48-69. Stanford: Stanford University Press.

Loriaux, M. 1999. "The French Developmental State as Myth and Moral Ambition.” In M. WooCumings, ed., The Developmental State. Pp. 235-275. Ithaca, NY: Cornell University Press.

Lundvall, B.A., B. Johnson, E.S. Andersen, B. Dalum, 2002. "National Systems of Production, Innovation and Competence Building." Research Policy (31,2): 213-231.

Luzio, E. 1996. The Microcomputer Industry in Brazil: The Case of a Protected High-Technology Industry. Westport, CT: Praeger.

Malerba, F. 2003. "Sectoral Systems: How and Why Innovation Differs Across Sectors.” In J. Fagerberg et al., Oxford Handbook of Innovation. Oxford, U.K.: Oxford University Press

Markusen, A., P. Hall, and A. Glasmeier. 1986. High Tech America: The What, How, Where and Why of the Sunrise Industries. London and Boston: Allen and Unwin.

McKendrick, D. 2000. From Silicon Valley to Singapore. Stanford: Stanford University Press.

McNeil, W. 1982. The Pursuit of Power: Technology, Armed Force and Society since A.D. 1000. Chicago: Chicago University Press

Meaney, C. 1994. "State Policy and the Development of Taiwan's Semiconductor Industry" In J.D. Aberbach et al., eds., The Role of the State in Taiwan's Development. Pp. 170-192. Armonk, NY: M.E. Sharpe. 
Mowery, D.C. 2001. "Technological Innovation in a Multipolar System: Analysis and Implications for U.S. Policy." Technological Forecasting and Social Change 67: 43-157.

Newman, N. 2002. Net Loss: Government, Technology and the Political Economy of Community in the Age of the Internet. Ann Arbor: University of Michigan Press.

OECD. 2002. Information Technology Outlook 2002. Paris: OECD.

Ó Riain, S. 2000. "The Flexible Developmental State, Globalization, Information Technology and the 'Celtic Tiger."' Politics and Society 28, 3: 3-37.

. 2004. The Politics of High Tech Growth. Cambridge: Cambridge University Press.

Parthasarathy, B. 2004. "India's Silicon Valley or Silicon Valley's India? Socially Embedding the Computer Software Industry in Bangalore." International Journal of Urban and regional Research 28, 3: 664-685.

Perez, C. 2002. Technological Revolutions and Financial Capital: The Dynamics of Bubbles and Golden Ages. Cheltenham, U.K.: Edward Elgar.

Porter, A., J.D. Roessner, N. Newman, and X.Y. Jin. 2000. 1999 Indicators of Technology-Based Competitiveness of 33 Nations: Summary Report. Washington D.C.: National Science Foundation.

Rodrik, D. 1997. "TFPG Controversies, institutions, and Economic Performance in East Asia" NBER Working Paper 5914, National Bureau of Economic Research: Cambridge, MA.

Roper, S., and A. Frenkel. "Different Paths to Success? The Growth of the Electronics Sector in Ireland and Israel" Working Paper No. 39, Northern Ireland Economic Research Centre, Queen's University, Belfast, 1998.

Saxenian, A. 1994. Regional Advantage:Culture and Competition in Silicon Valley and Route 128. Cambridge, MA: Harvard University Press.

. A. 1999. Silicon Valley's New Immigrant Entrepreneurs. San Francisco: Public Policy Institute of California.

Saxenian, A., and J. Y. Hsu. 2001. "The Silicon Valley-Hsinchu Connection: Technical Communities and Industrial Upgrading." Industrial and Corporate Change 10, 4

Sokolov, M., and E. M. Verdoner. 1997. "The Israeli Innovation Support System-Generalities and Specifics" Working paper presented at Conference on Technology Policy and Less Developed Research and Development Systems in Europe, Seville, October.

Soskice, D., and P. Hall, eds., 2001. Varieties of Capitalism Oxford: Oxford University Press.

Steinmuller, E. 1996. “The U.S. Software Industry: An Analysis and Interpretive History.” In D. Mowery, ed., The International Computer Software Industry. Pp. 15-52. Oxford: Oxford University Press.

Sturgeon, T. 2000. "How Silicon Valley Came to Be" In M. Kenney, ed., Understanding Silicon Valley. Pp. 15-47 Stanford: Stanford University Press.

. 1999. "Network-Led Development and the Rise of Turn-key Production Networks: Technological Change and the Outsourcing of Electronics Manufacturing." In G. Gereffi, F. Palpacuer, A. Parisotto, eds., Global Production and Local Jobs. Geneva: International Institute for Labor Studies.

Vonortas, N. S., and S. P. Safioleas. 1997. "Strategic Alliances in Information Technology and Developing Country Firms: Recent Evidence." World Development 25, 5: 657-680.

Wade, R. 1990. Governing the Market. Cambridge: Cambridge University Press.

Woo-Cumings, M., ed., 1999. The Developmental State. Ithaca, NY: Cornell University Press. 
Copyright of Studies in Comparative International Development is the property of Transaction Publishers and its content may not be copied or emailed to multiple sites or posted to a listserv without the copyright holder's express written permission. However, users may print, download, or email articles for individual use. 